\title{
LETTER
}

\section{Mechanical insufflation-exsufflation in prevention of post-extubation acute respiratory failure: most welcome but must be used cautiously in critically ill patients}

\author{
Antonio M Esquinas Rodriguez ${ }^{* 1}$ and Egbert Pravinkumar² \\ See related research by Gonçalves et al., http://ccforum.com/content/16/2/R48
}

In a study published in the previous issue of Critical Care, Gonçalves and colleagues [1] observed a 33\% reduction in re-intubation rate in the study group, due to effective management of bronchial secretions. Current evidence favors early implementation of noninvasive mechanical ventilation (NIV) in the post-extubation period to reduce re-intubation, especially in patients with hypercapnic respiratory failure [2-4].

However, some important practical issues need to be considered before the use of mechanical insufflationexsuflation (MI-E) in the post-extubation period can be generalized, especially in patients needing NIV: (a) MI-E application requires that the NIV mask be disconnected, resulting in positive pressure loss, alveolar collapse, and desaturation. (b) MI-E devices do not have entrained oxygen. Hence, any rapid desaturation episode will require immediate reconnection to NIV. (c) Assessment of the effective management of bronchial secretions can prove difficult because of the lack of an objective or specific scoring system. (d) In some situations requiring several MI-E sessions, frequent disconnection from NIV can lead to prolonged use of post-extubation NIV. (e) MI-E may be difficult to perform or may lead to poor compliance in cases of unplanned extubation, moderate to severe hypoxemic acute respiratory failure (ARF) after extubation, agitation/anxiety, and tachypnea. (f) The effectiveness of MI-E should be studied beyond 48 hours, as late-onset extubation failures and post-extubation NIV failures are due mostly to ineffective secretion clearance [5].

\footnotetext{
*Correspondence: antmesquinas@gmail.com

'Intensive Care Unit, Hospital Morales Meseguer, Avd Marques Velez s/n, Murcia, Spain 30.008

Full list of author information is available at the end of the article
}

In conclusion, we believe that this original study could have an impact on the management and prevention of post-extubation ARF in a select group of patients. However, owing to the above-mentioned reasons, the use of MI-E cannot be generalized to all patient populations.

\section{Abbreviations \\ $A R F$, acute respiratory failure; $M I-E$, mechanical insufflation-exsuflation; NIV, noninvasive mechanical ventilation.}

\section{Competing interests}

The authors declare that they have no competing interests.

\section{Author details}

IIntensive Care Unit, Hospital Morales Meseguer, Avd Marques Velez s/n, Murcia Spain 30.008. ${ }^{2}$ Department of Critical Care and Department of Anesthesiology, UT Health, Unit 112, UT-M.D. Anderson Cancer Center, Houston, TX 77030, USA.

Published: 19 June 2012

\section{References}

1. Gonçalves MR, Honrado T, Winck JC, Paiva JA: Effects of mechanical insufflation-exsufflation in preventing respiratory failure after extubation: a randomized controlled trial. Crit Care 2012, 16:R48.

2. Ferrer M, Valencia M, Nicolas JM, Bernadich O, Badia JR, Torres A: Early noninvasive ventilation averts extubation failure in patients at risk: a randomized trial. Am J Respir Crit Care Med 2006, 173:164-170.

3. Keenan SP, Powers C, McCormack DG, Block G: Noninvasive positivepressure ventilation for postextubation respiratory distress: a randomized controlled trial. JAMA 2002, 287:3238-3244

4. Esteban A, Frutos-Vivar F, Ferguson ND, Arabi Y, Apezteguía C, González M, Epstein SK, Hill NS, Nava S, Soares MA, D’Empaire G, Alía I, Anzueto A: Noninvasive positive-pressure ventilation for respiratory failure after extubation. N Engl J Med 2004, 350:2452-2460.

5. Antonelli M, Conti G, Moro ML, Esquinas A, Gonzalez-Diaz G, Confalonieri M, Pelaia P, Principi T, Gregoretti C, Beltrame F, Pennisi MA, Arcangeli A, Proietti R, Passariello M, Meduri GU: Predictors of failure of noninvasive positive pressure ventilation in patients with acute hypoxemic respiratory failure: a multi-center study. Intensive Care Med 2001, 27:1718-1728.

\section{doi:10.1186/cc11373}

Cite this article as: Esquinas Rodriguez AM, Pravinkumar E: Mechanical insufflation-exsufflation in prevention of post-extubation acute respiratory failure: most welcome but must be used cautiously in critically ill patients. Critical Care 2012, 16:431. 